\title{
Growing Caisim (Brassica juncea L.) Using Elaeisponic Production System
}

\author{
Jusrian Saubara Orpa Yanda, Fahrurrozi Fahrurrozi* and Supanjani Supanjani \\ Department of Crop Production, Faculty of Agriculture, University of Bengkulu \\ WR Supratman St, Kandang Limun, Bengkulu 38371, Indonesia
}

\author{
ARTICLE INFO \\ Keywords: \\ Elaeisponic Production System \\ Brassica juncea L. \\ Foliar Fertilizer \\ Frequency of Application. \\ Article history: \\ Received: July 18, 2018 \\ Accepted: Nov 20, 2018 \\ *Corresponding author: \\ E-mail: fahrurrozi@unib.ac.id
}

\begin{abstract}
Elaeisponic is new introducing growing technique to produce vegetables by planting it in the frond based of oil palm trees (Elaeis guineensis Jacq.). However, there was no previous report on vegetable production by using elaeisponic production system, including the use of foliar fertilizers. This study aimed to determine the optimum consentrations and frequency of foliar fertilization for caisim grown in elaesisponic production system. An experiment was conducted in oil palm plantation area by using a factorial randomized complete block design with three replicates. The first factor of treatment consisted of three levels of foliar fertilizer concentration, $1 \mathrm{~g} \mathrm{l}^{-1}, 2 \mathrm{~g} \mathrm{l}^{-1}$ and 3 $\mathrm{g} \mathrm{l}^{-1}$, and the second factor was application frequency of foliar fertilizer, 7 days after transplanting (DAT), 7, 14 DAT and 7, 14, 21 DAT. Crop responses were determined on leaf greenness (SPAD index), shoot fresh weight $(\mathrm{g})$, root fresh weight $(\mathrm{g})$, leaf area $\left(\mathrm{cm}^{2}\right)$ and plant dry weight. Results indicated that both concentration of foliar fertilizer and frequency of application as wells as its interaction did not significatly affect leaf greenness, leaf area, shoot fresh weight, root fresh weight and plant dry weight of caisim plants. Further research should be addressed on optimizing the use of palm oil frond bases as growing medium for vegetable production.
\end{abstract}

\section{INTRODUCTION}

The term of elaeisponic refers to growing technique to produce vegetables by planting it in the frond based of oil palm trees (Elaeis guineensis Jacq.). This technique is not popular yet, but is potentially introduced as an alternative technique to grow vegetables by using bases of oil palm fronds (Figure 1). When an oil palm tree got pruning, the leaf bases could adhere to the stem for about more than 12 years and fall away gradually. Field observations revealed that weeds are commonly growing in the frond bases of an oil palm tree since it contained organic materials accumulated from the leaf debris other plant parts and is able to conserve rain water. In addition, the sizes of frond bases is likely able to support shallow-rooted and short life -cycled vegetables. With the increasing acreages of oil palm plantations in Indonesia, vegetable production in the frond bases are expected to provide additional areas for vegetable production. In each oil palm trees, circular position of the fronds allows to grow more than one vegetable plant which eventually provides a verticulture technique to produce vegetables.

Although the frond bases might serve as growing media and provide sufficient nutritions to any vegetables grown in it, the proposed plants are likely required additional nutrition and growing media to have better stands. Other concern was related to shading effects of oil palm trees inwhich shading tolerant vegetables and crop arrangement should be innovatively considered. Leafy vegetable of caisim (Brassica juncea L.) is considered as a fast growing vegetable and is able to adapt with size of oil palm fronds bases since this vegetable has shallow root type and shading tolerant species (Decoteau, 2000). According to Nilsen and Orcutt (1996) shading tolerance could be enhanced by maintaining sufficient fertilizer to the crops. Hence, additional fertilizer is crucially important to vegetables grown using elaeisponic production system. Since the growing media in the frond is less feasible for application of solid fertilizer, foliar fertilizers might increase nutrient availability for caisim grown in elaesisponic production system. Novizan (2002) emphasized that foliar fertilization might accelerate nutrient absorption to improve crop growth and prevent root damaged from high dosage of solid fertilization in the growing media. Although many experiments have been addressed to the use of foliar fertilizer in caisim production, caisim production using elaesisponic production system has not been documented. Accroding to Haytova (2013), effectiveness of foliar fertilizing is determined by the crop species, fertilizer form, concentration, frequency of application and the stage of

ISSN: $1410-3354$ / e-ISSN:2615-7136

Cited this as: Yanda, J.S.O., Fahrurrozi and Supanjani. 2018. Growing caisim (Brassica juncea L.) using elaeisponic production System. Akta Agrosia 21(2):29-32. 
plant growth. Studies on effects of foliar fertilizer on leafy vegetables under conventional production systems have been well documented (e.g.Nursanti et al., 2010; Nasution et al., 2014; Ramadiani et al., 2014). However, there were no previous reports on vegetable production by using elaeisponic production system, including the use of foliar fertilizers.

This preliminary study aimed to determine the optimum consentrations and frequency of foliar fertilization for caisim grown in elaesisponic production system.

\section{MATERIALS AND METHOD}

This experiment was conducted from May to June 2016 in oil palm plantation area in Pematang Gubernur, Muara Bangkahulu, Bengkulu, using a factorial randomized complete block design with three replicates. The oil palm plants were ten years old, grown in triangle arrangement and nine meters. The first factor of treatments consisted of three levels of foliar fertilizer concentration, (1) $1 \mathrm{~g} \mathrm{l}^{-1}$, (2) $2 \mathrm{~g} \mathrm{l}^{-1}$ and (3) $3 \mathrm{~g} \mathrm{l}^{-1}$, and the second factor was application frequency of foliar fertilizer, (1) 7 days after transplanting (DAT), (2) 7 and 14 DAT and (3) 7, 14, and 21 DAT. In each oil palm plants, twelve caisim plants were circularly planted in twelve different frond bases at the minimum height of 1.5 meter above the ground surface (Figure 1). This height was presumably safe for the caisim plants from pig or goat attacks and manageable by farmers.

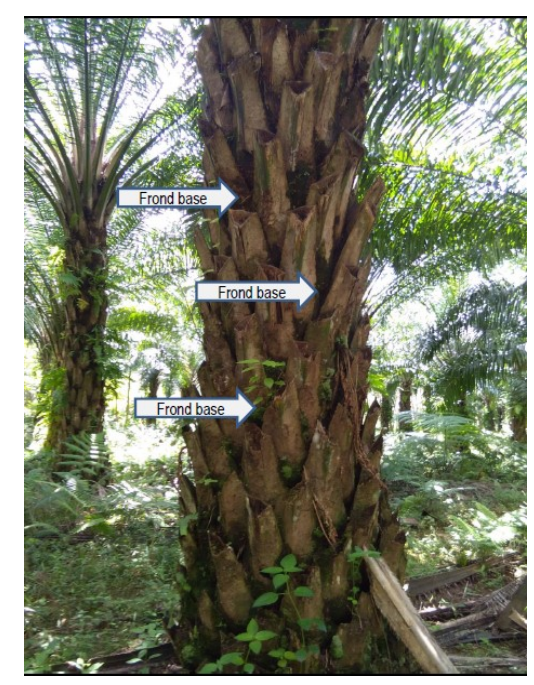

Figure 1. Frond bases of oil palm as media for elaeisponic production system (Photo by Fahrurrozi)

Two weeks old of caisim (var. Tosakan) seedlings were transplanted into the frond bases with additional growing media of $0.5 \mathrm{~kg}$ of oil palm composts. Oil palm based composted was commercially produced by PT Bio Nusantara Teknologi, Bengkulu Tengah which contained $4.59 \%$ N-Total, $7.67 \% \mathrm{P}_{2} \mathrm{O}_{5}, 4.93 \% \mathrm{~K}_{2} \mathrm{O}, 21.11 \% \mathrm{C}$ Organic and $32.75 \%$ of water content (Pusat Penelitian Kelapa Sawit, 2014). Foliar fertilizer (Gandasil-D ${ }^{\mathrm{TM}}$ ) was applied to each plants, complied with treatments, uniformly bathing the plant surface by using hand sprayer. When there was no rain, plants were watered as necessary. Weeds grown in frond bases were manually removed. Caisisms were harvested at five weeks after transplanting.

Crop responses were determined on leaf greenness (SPAD index), shoot fresh weight $(\mathrm{g})$, root fresh weight $(\mathrm{g})$, leaf area $\left(\mathrm{cm}^{2}\right)$ and plant dry weight. All data were subjected to analysis of variance, after a homogeneity test, by using PROC GLM in Statistical Analysis System at
$\mathrm{P}<0.05$. Means of treatment effects were compared using Least Significantly Different test 5\%. Supporting data included light intensity (lux), air temperature $\left({ }^{\circ} \mathrm{C}\right)$ and humidity $(\%)$ in each replicate were diagonally collected from the experimental sites. Average daily rainfall $(\mathrm{mm})$, daily air temperatures and daily humidity (\%) were also collected from the nearest Meteorological Station.

\section{RESULTS AND DISCUSSION}

\section{Environmental condition}

Microclimate condition in the experimental site as indicated by light intensity (lux), air temperature $\left({ }^{\circ} \mathrm{C}\right.$ ), and air humidity $(\%)$ are presented in Table 1 . It was clear that shading effect of 10 years old oil palms brought about siginificant changes to light intensity, air temperature, and air humidity compared to those of under open field. In general, light intensity and air temperatures were lower under oil palm plantation than those of under open field. Gradual decrease of these parameters might be related to the slope of experimental site which was approximately accounted as much as $15 \%$. However, air humidity was higher under oil palm plantation than that of under open field. Data from the nearest Meteorological Station indicated that the average daily rainfall, daily air temperatures and daily humidity in May 2016 were $13.95 \mathrm{~mm}, 27.8{ }^{\circ} \mathrm{C}$ and $85.3 \%$, respectively, while on June were $6.035 \mathrm{~mm}$, $27.3{ }^{\circ} \mathrm{C}$ and $81 \%$, respectively.

Table 1. Microclimate conditions in the experimental site (Taken at 09.00 hours)

\begin{tabular}{llll}
\hline $\begin{array}{c}\text { Measurement } \\
\text { Locations }\end{array}$ & $\begin{array}{c}\text { Light in- } \\
\text { tensity } \\
(\text { lux })\end{array}$ & $\begin{array}{c}\text { Air tem- } \\
\text { perature } \\
\left({ }^{\circ} \mathrm{C}\right)\end{array}$ & $\begin{array}{c}\text { Humidity } \\
(\%)\end{array}$ \\
\hline Open field & 103300 & 35 & 39 \\
Block 1 & 8814 & 33,16 & 47,2 \\
Block 2 & 5117 & 32,22 & 48,8 \\
Block 3 & 4548 & 32,32 & 50,2 \\
\hline
\end{tabular}

\section{Growth and Yields}

Results indicated that concentration of foliar fertilizer did not significatly affect leaf greenness $(\mathrm{P}>0.4100)$, leaf area $(\mathrm{P}>0.9552)$ shoot fresh weight $(\mathrm{P}>0.9493)$, root fresh weight $(\mathrm{P}>0.6337)$, and plant dry weight $(\mathrm{P}>0.9006)$ of caisim plants. The effects of foliar fertilizer concentration are presented in Table 2 . The effects of application frequency of foliar fertilizer did not significatly affect leaf greenness $(\mathrm{P}>0.8924)$, leaf area $(\mathrm{P}>0.8670)$, shoot fresh weight $(\mathrm{P}>0.7536)$, root fresh weight $(\mathrm{P}>0.9216)$ and plant dry weight $(\mathrm{P}>0.9103)$ of caisim plants. The effects of application frequency are presented in Table 3. This experiment also revealed that there was no interaction between concentration and application frequency on leaf greenness, leaf area, shoot fresh weight, root fresh weight and plant dry weight with $\mathrm{P}>0.4796, \mathrm{P}>0.4271, \mathrm{P}>0.5159, \mathrm{P}>0.5461$ and $\mathrm{P}>0.4725$, respectively.

Although results from this experiment suggested that all treatments have no effects on leaf greenness, leaf area, shoot fresh weight, root fresh weight, and plant dry weight, elaeisponic growing technique is still considered a potential media for vegetable production. Further elaeisponic production technologies should be developed. It was clear that light interception under oil palm canopy drastically reduced as results of shading effects (Table 1). For example, light interception under oil palm canopy in 
replicate one was only $8.53 \%$ from that on an open field (8,814 lux vs. 103,300 lux), while light interception in replicates two and three was only $4.95 \%$ and $4.40 \%$ from that on an open field. According to Telaumbanua et al. (2016) caisim requires light intensity of 17.000 lux $(16.45 \%)$ of full sunlight) to have optimum growth and yield. indicated that caisims grown under stress condition, i.e. low light intensity, tended to complete its life cycle earlier since one of the plant started to flowering at 20 days after transplanting. According to Karamoy (2009), shading condition induced plants to start flowering. Such enhancement also might reduce the time for crop to

Table 2. Effects of foliar fertilizer concentrations on leaf greenness (LG), leaf area (LA, shoot fresh weight (SFW), root fresh weight (RFW) and plant dry weight (PDW)

\begin{tabular}{llllll}
\hline $\begin{array}{l}\text { Concentrations of Foli- } \\
\text { ar Fertilizer }\end{array}$ & LG & $\begin{array}{l}\text { LA } \\
\left(\mathrm{cm}^{2}\right)\end{array}$ & $\begin{array}{l}\text { SFW } \\
(\mathrm{g})\end{array}$ & $\begin{array}{l}\text { RFW } \\
(\mathrm{g})\end{array}$ & $\begin{array}{l}\text { SDW } \\
(\mathrm{g})\end{array}$ \\
\hline $1 \mathrm{~g} \mathrm{l}^{-1}$ & 32.63 & 299.46 & 11.91 & 0.33 & 1.05 \\
$2 \mathrm{~g} \mathrm{l}^{-1}$ & 32.77 & 283.27 & 11.36 & 0.24 & 0.95 \\
$3 \mathrm{~g} \mathrm{l}^{-1}$ & 32.02 & 282.63 & 10.92 & 0.19 & 0.90 \\
\hline
\end{tabular}

Under shading condition, nutrient absorption through leaf stomata and cuticles became less effective due to aperture closures. Light intensity has a pronounced effect on stomata opening and closure. According to Taiz and Zeiger (2010), sufficient light intensity will stimulate the guard cells to absorb $\mathrm{K}^{+}$ions and water to open stomata apertures. Research conducted by Haryanti (2010) concluded that shading decreased the number of stomata in pink rain lily (Zephyranthes Rosea Lindl.). Since stomata of caisims was relatively closed due to shading effects of oil palm plants, foliar application of fertilizer within the range of $1-3 \mathrm{~g} \mathrm{l}^{-1}$ concentrations was not sufficient to compensate the shading effects. It seemed that higher concentration would be beneficial to caisim grown under elaeisponic system. Furthermore, low growth of caisim could also be attributed to low leaf chlorophyll content as indicated by leaf greenness (31-33 according to SPAD index, Table 2 and Table 3 ). These values were considered low as leaf greenness of caisim plants grown under open field could range from 40 to 45 . Low leaf greenness was undoubtedly related to low light penetration to oil palm canopies. According to Taiz and Zeiger (2010) sun light induces the activation of photochloroplast to synthesis chlorophylls. Results also inferred that low fresh weight of caisim leaves were related to leaf thickness of caisim leaves. Results from this experiment indicated that the ratio of shoot fresh weight to leaf area was very low which later indicated that caisim leaves were thin. Under this condition, it was not only photosynthesis rates declined, but also nutrient absorption decreased (Nilsen and Orcutt, 1996). In addition to using higher concentration of foliar fertilizer, caisim growth and yield using elaeisponic system could be improved by using surfactant during the application of foliar fertilizer. According Holloway and Stock (1990) surfactant improved liquid foliar fertilizing in many plants. Marschner (2012) summarized several problems in foliar application, including poor leaf absorption in absence of adjuvants, spray running-off, washing off by rain, leaf structure barrier, rap drying of spray, limited rates of distribution of certain nutrient, limited amount of macronutrient can be applied without inducing phototoxicity. In addition, this experiment also accumulate photosynthate in harvesting plant-parts.

Yields of caisims, indicated by it fresh weight, were very much lower than its genetic potential of this caisim variety. Results from this experiment indicated that the fresh weights of this crop ranged only from 11 to $12 \mathrm{~g}$ per plant, which was very much lower than its variety description (93 to 116 g per plant). Such comparison might not be suitable, but at least it provided information of how much individual performance of caisim grown by using elaeisponic system. Caisim fresh weights from this experiment were lower than those grown in the polybag (i.e. $54 \mathrm{~g}$ per plant), or than those grown on soil beds (i.e. $75 \mathrm{~g}$ per plant).

\section{CONCLUSION}

The use of foliar fertilizer to support growth of caisims grown under elaeisponic growing system did not significantly improve caisims growth and yields. Both foliar fertilizer concentrations and frequency of application did not increase caisim growth and yield. Although the results from this experiment indicated that caisim fresh weight was not as expected, growing caisim in the frond bases of oil palm might be considered since it serves as growing media and provides sufficient nutritions to any vegetables. Further research should be addressed on optimizing the use of oil palm frond bases as growing medium for vegetable production.

\section{REFERENCES}

Decoteau, D.R. 2000. Vegetable Crops. Prentice Hall. Upper Saddle River, NJ.

Haryanti, S. 2010. Pengaruh naungan yang berbeda terhadap jumlah stomata dan ukuran porus stomata daun Zephyranthes Rosea Lindl. Buletin Anatomi dan Fisiologi. 18 (1) : 41-48

Haytova, D. 2013. A review of foliar fertilization of some vegetable crops. Annual Review and Research in Biology. (4):455-465.

Holloway, P.J. and D. Stock. 1990. Factors affecting the activation of foliar uptake of agrochemicals by

Table 3. Effects of application frequency of foliar fertilizer on leaf greenness (LG), leaf area (LA), shoot fresh weight (SFW), root fresh weight (RFW) and plant dry weight (PDW)

\begin{tabular}{lrrrrr}
\hline Application Frequency of Foliar Fertilizer & LG & LA $\left(\mathrm{cm}^{2}\right)$ & $\begin{array}{c}\text { SFW } \\
(\mathrm{g})\end{array}$ & RFW $(\mathrm{g})$ & $\begin{array}{c}\text { SDW } \\
(\mathrm{g})\end{array}$ \\
\hline 7 days after transplanting & 32.64 & 276.46 & 10.66 & 0.24 & 0.96 \\
7 and 14 days after transplanting & 31.74 & 285.64 & 11.31 & 0.27 & 0.94 \\
7, 14 and 21 days after transplanting & 33.05 & 303.28 & 12.24 & 0.26 & 1.01 \\
\hline
\end{tabular}


surfactants. In: D.S. Karsa (ed.), Industrial application of surfactants II. London, Royal Society of Chemistry. Special publication. 77:303-337.

Karamoy, L.T. 2009. Hubungan iklim dengan pertumbuhan kedelai (Glycine max L Merrill). Soil Environment 7: 65-68.

Marschner, H. 2012. Marschner's Mineral Nutrition of Higher Plants. $3^{\text {rd }}$ ed. London. Academic Press.

Nasution, A.S., S.S. Awalluddin dan Muhammad. 2014. Pemberian pupuk ABG (Amazing Bio Growth) dan pupuk kompos terhadap pertumbuhan dan produksi tanaman sawi hijau (Brassica juncea L.). Jurnal Agrium. 18(3):260-268.

Nilsen, E.T. and D.M. Orcutt. 1996. Physiology of Plants Under Stress. Abiotic Factors. John Wiley and Sons. New York. 689 pages.

Novizan. 2002. Petunjuk Pemupukan yang Efektif. Agromedia Pustaka, Jakarta.
Nurshanti, D.F. 2010. Pertumbuhan dan produksi tanaman sawi (Brassica juncea L.) dengan tiga varietas berbeda. Jurnal Agroekoteknologi. 2(4):41-54

Pusat Penelitian Kelapa Sawit. 2014. Sertifikasi analisis hasil uji pupuk organik padat PT Bio Teknologi Bengkulu Tengah. Medan.

Ramadiani, F.L. dan A.D. Susila. 2014. Sumber dan frekuensi aplikasi larutan hara sebagai pengganti $A B$ Mix pada budidaya sayuran daun secara hidroponik. Jurnal Hortikultura Indonesia 5(1):34-46.

Taiz, L. and E. Zeiger. 2010. Plant Physiology. $5^{\text {th }}$ Ed. Sinauer Associate Sunderland

Telaumbanua, M., P. Bambang., S. Lilik., A.F.F. Muhammad. 2016. Studi pola pertumbuhan tanaman sawi (Brassica rapa var. parachinensis L.) hidroponik di dalam greenhouse terkontrol. Jurnal Agritech 36 (1): 104-110. 